Buletin JSJ, 3 (2), 2021, 63-69

Available online di: http://ejournal-balitbang.kkp.go.id/index.php/JSJ/index

\title{
KARAKTERISTIK SENSORI KAMABOKO CUMI-CUMI (Loligo sp.) DENGAN VARIASI PENGGUNAAN TEPUNG TAPIOKA DAN NaCl
}

\section{SENSORY CHARACTERISTICS OF KAMABOKO SQUID (Loligo SP.) WITH VARIATIONS OF USE OF TAPIOKA FLOUR AND NaCI}

\author{
Aulia Azka ${ }^{1}$, Muh Suryono, Indah Sari Pratiwi \\ ${ }^{1}$ Program Studi Pengolahan Hasil Laut, Politeknik Kelautan dan Perikanan Dumai, \\ JI. Wan Amir No.1, Dumai Barat, Kota Dumai; Telepon: (0765) 4302660 \\ *Email: azkaa8586@gmail.com
}

\begin{abstract}
ABSTRAK
Cumi-cumi (Loligo sp.) merupakan komoditas yang banyak ditemukan di perairan Indonesia. Cumi-cumi dapat diolah menjadi kamaboko. Kamaboko adalah olahan daging ikan yang memiliki kekuatan gel yang homogen. Tujuan penelitian ini yaitu untuk mengetahui karakteristik sensori kamaboko cumi-cumi (Loligo sp.) dengan variasi penggunaan konsentrasi tepung tapioka dan $\mathrm{NaCl}$. Metode penelitian menggunakan metode eksperimental dengan 3 perlakuan, produk diuji sensori oleh 30 orang panelis untuk mengetahui karakteristik sensori kamaboko. Kamaboko cumi-cumi dengan variasi konsentrasi tepung tapioka dan $\mathrm{NaCl}$ terdiri dari tiga perlakuan yaitu tepung tapioka $6 \%$ \& $\mathrm{NaCl} 3 \%(\mathrm{~K} 1)$, tepung tapioka 9\% \& $\mathrm{NaCl} 6 \%(\mathrm{~K} 2)$, tepung tapioka $12 \%$ \& $\mathrm{NaCl} 9 \%(\mathrm{~K} 3)$. Hasil penelitian menunjukkan bahwa kamaboko cumi-cumi dengan variasi penggunaan tepung tapioka dan $\mathrm{NaCl}$ memberikan pengaruh yang berbeda nyata terhadap penilaian panelis pada parameter rasa, tekstur, uji lipat dan uji gigit. Perlakuan yang terbaik yaitu perlakuan K2 dengan komposisi tepung tapioka $9 \%$ dan $\mathrm{NaCl} 6 \%$, dimana semua parameter panelis memberikan penilaian tertinggi.
\end{abstract}

Kata Kunci: Cumi-cumi, Kamaboko, Sensori

\section{ABSTRACT}

Squid (Loligo sp.) is a commodity that is commonly found in Indonesian waters. Squid can be processed inti kamaboko. Kamaboko is processed fsih meat that has a homogeneous gel strength. The purpose of this study was to determine the sensory characterustucs of squid kamanoko with variations in the use of tapioca flour and $\mathrm{NaCl}$ concentrations. The research method used an experimental method with 3 treatments, the product was sensory tested by 30 panelists to determine the sensory characteristics of kamaboko. Squid kamaboko with various concentrations of tapioca flour and $\mathrm{NaCl}$ consisted of $6 \%$ tapioca flour \& $3 \% \mathrm{NaCl}$ (K1), $9 \%$ tapioca flour \& $6 \% \mathrm{NaCl}(\mathrm{K} 2), 12 \%$ tapioca flour \& $9 \% \mathrm{NaCl}(\mathrm{K} 3)$. The result showed that squid kamaboko with variations in the use of tapioca flour and $\mathrm{NaCl}$ gave a significantly different effect on panelist assessment of the parameters of taste, texture, folding test, and bite test. The best treatment wa K2 treatment with $9 \%$ tapioca flour an $6 \%$ $\mathrm{NaCl}$, where all panelist gave the highest rating.

Keywords: Squid, Kamaboko, Sensory

\section{PENDAHULUAN}

Cumi-cumi (Loligo sp.) merupakan komoditas yang banyak ditemukan di perairan Indonesia.Cumi-cumi memiliki daging putih yang menjadi kelebihan sehingga disukai oleh masyarakat. Produksi cumi sotong gurita (CSG) periode 2010-2017 di Indonesia mengalami 
peningkatan tertinggi terjadi pada tahun 2015, yaitu meningkat 44,73 dibandingkan tahun 2014. Tahun 2015 produksi CSG Indonesia sebesar 254 ribu ton atau sekitar $6,13 \%$ dari total CSG dunia. Tahun 2017 Indonesia menjadi negara terbesar produsen CSG urutan ketiga dengan produksi sebesar 191 ribu ton (BPS, 2019). Cumi-cumi bersifat high perishable food sehingga diperlukan pengolahan yang tepat agar cita rasanya tidak berkurang (Hulalata, 2013). Cumi-cumi dapat diolah menjadi seperti cumi-cumi bakar, hidangan seafood, cumi asin kering, dan cumi-cumi beku. Selain itu cumi-cumi juga dapat dibuat menjadi kamaboko.

Kamaboko adalah olahan daging ikan yang memiliki kekuatan gel yang homogen, produk ini dari negara Jepang. Produk analog kamaboko di Indonesia yaitu pempek dan bakso ikan. Mao et al. (2006) menyatakan bahwa faktor-faktor yang mempengaruhi sifat elastis kamaboko yaitu jenis ikan dan bahan tambahan. Berdasarkan penelitian Hasnelly (2020) menunjukkan bahwa kamaboko dengan substitusi tepung ubi jalar dan tinta cumicumi berpengaruh terhadap warna, aroma, tekstur kekenyalan, kadar air, dan kadar protein kamaboko.

Tepung tapioka adalah granula pati dari umbi ketela pohon yang tinggi kadar karbohidrat. Tepung tapioka memiliki daya lekat tinggi dan tidak mudah menggumpal karane tinggi kandungan amilopektin (Lekahena, 2016). Dalam pembuatan kamaboko tepung tapioka ditambahkan sebagai menstabilkan emulsi, meningkatkan daya, mengikat air, memperkecil penyusutan, menambah berat produk dan karena harganya relatif murah maka dapat menekan biaya produksi. Penambahan garam pada pembuatan kamaboko berfungsi sebagai flavor. Garam juga diberikan pada awal penggilingan agar meningkatkan kekuatan gel. Penelitian ini bertujuan untuk mengetahui karakteristik sensori kamaboko cumi-cumi (Loligo sp.) dengan penggunaan variasi konsentrasi tepung tapioka dan $\mathrm{NaCl}$ berbeda.

\section{BAHAN DAN METODE}

Bahan yang digunakan dalam penelitian ini adalah cumi-cumi, tepung tapioka, tepung maizena, garam, air, gula, merica, dan es curai. Peralatan yang digunakan antara lain meat grinder, talenan, kompor, baskom, timbangan digital, food processor, panci.

Metode penelitian ini yaitu metode eksperimental menggunakan 3 perlakuan dengan 30 orang panelis sebagai ulangan, untuk mengetahui karakteristik sensori kamaboko. Tiga perlakuan terdiri dari Tepung tapioka $6 \% \& \mathrm{NaCl} 3 \%(\mathrm{~K} 1)$, tepung tapioka $9 \%$ \& $\mathrm{NaCl} 6 \%$ (K2), tepung tapioka $12 \%$ \& $\mathrm{NaCl} 9 \%$ (K3). Panelis mengamati parameter rasa, aroma, warna, tekstur, uji lipat, dan uji gigit. Analisis data menggunakan uji Kruskall-Wallis yang dilanjutkan dengan uji lanjut Duncan untuk melihat pengaruh variasi penggunaan tepung tapioka dan $\mathrm{NaCl}$ yang digunakan terhadap karakteristik sensori kamaboko. Analisis data menggunakan software SPSS versi 26.0.

\section{HASIL DAN PEMBAHASAN}

\section{Rasa}

Kamaboko cumi-cumi diuji hedonik oleh 30 orang panelis dengan skala penilaian 1 (sangat tidak suka) - 5 (sangat suka). Nilai rata-rata parameter rasa kamaboko cumicumi berkisar dari 1,8-4,16 yang berarti panelis menilai dari tidak suka sampai suka. Nilai kesukaan tertinggi pada perlakuan K2 dengan komposisi tepung tapioka $9 \%$ dan $\mathrm{NaCl} 6 \%$ sebesar 4,16 (suka), sedangkan nilai kesukaan terendah pada perlakukan $\mathrm{K} 3$ dengan komposisi tepung tapioka $12 \%$ dan $\mathrm{NaCl} 9 \%$ sebesar 1,8 (tidak suka). Hasil parameter rasa dapat dilihat pada Gambar 1. 
Buletin JSJ, 3 (2), 2021, 63-69

Available online di: http://ejournal-balitbang.kkp.go.id/index.php/JSJ/index

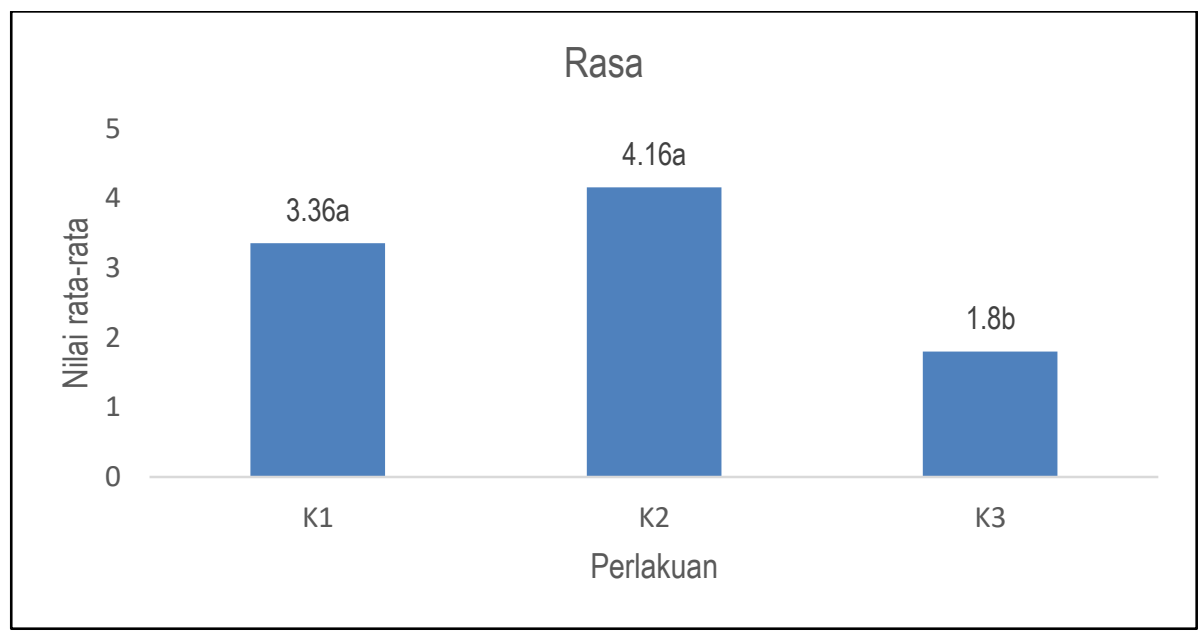

Gambar 1. Histogram parameter rasa.

Hasil analisis Kruskal-Wallis menunjukkan bahwa perbedaan konsentrasi tepung tapioka dan $\mathrm{NaCl}$ memberikan pengaruh terhadap rasa kamaboko. Hasil uji lanjut juga menunjukkan adanya perbedaan nilai rasa masing-masing perlakuan. Penelitian Sarofa et al. (2014) menunjukkan hasil yang sama bahwa rasa kamaboko ikan manyung dipengaruhi oleh konsentrasi tepung tapioka dan $\mathrm{NaCl}$. Anwar et al. (2019) menyatakan bahwa perbedaan konsentrasi tepung terigu memberikan pengaruh terhadap rasa kamaboko. Komponen gizi seperti karbohidrat, protein, dan lemak akan mempengaruhi rasa makanan (Suryaningrum, et al. 2000).

\section{Aroma}

Hasil pengujian menunjukkan nilai rata-rata parameter aroma kamaboko cumi-cumi 2,57-4,2 yang berarti panelis menilai dari netral sampai suka. Nilai kesukaan tertinggi pada perlakuan $\mathrm{K} 2$ dengan komposisi tepung tapioka $9 \%$ dan $\mathrm{NaCl} 6 \%$ sebesar 4,2 (suka), sedangkan nilai kesukaan terendah pada perlakukan K3 dengan komposisi tepung tapioka $12 \%$ dan $\mathrm{NaCl} 9 \%$ sebesar 2,57 (netral). Hasil parameter aroma dapat dilhat pada Gambar 2.

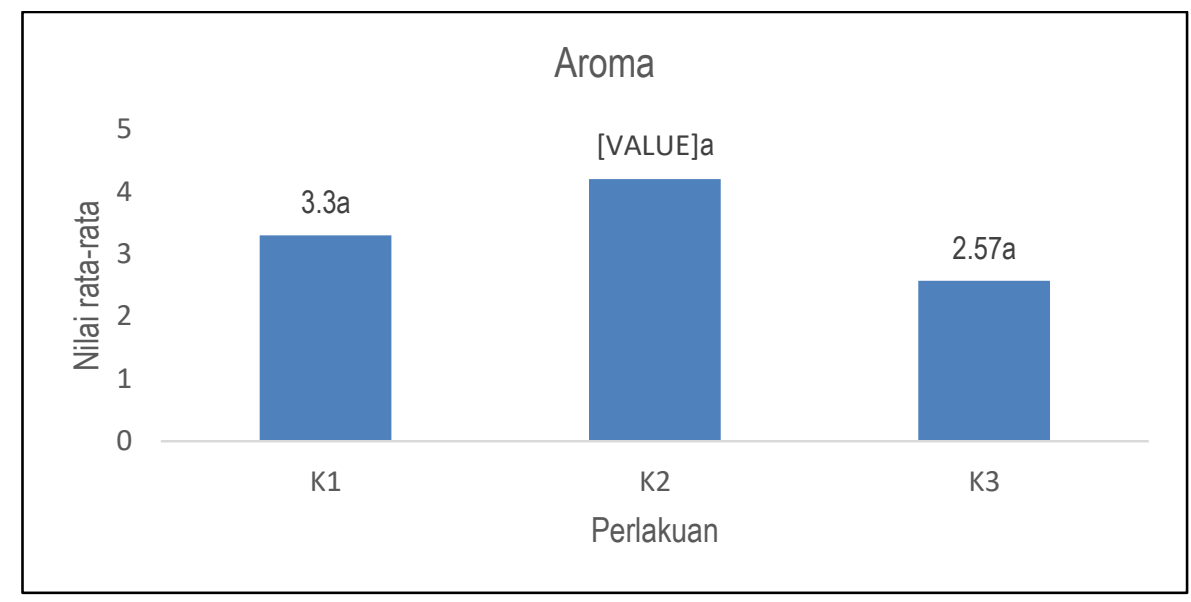

Gambar 2. Histogram parameter aroma.

Hasil analisis Kruskal - Wallis menunjukkan bahwa perbedaan konsentrasi tepung tapioka dan $\mathrm{NaCl}$ tidak memberikan pengaruh terhadap aroma kamaboko. Hal ini dikarenakan tepung tapioka memiliki aroma yang netral sehingga tidak mempengaruhi aroma kamaboko. Penelitian Anwar et al. (2019) menunjukkan hasil yang sama bahwa tepung terigu tidak 
Buletin JSJ, 3 (2), 2021, 53-62

Available online di: http://ejournal-balitbang.kkp.go.id/index.php/JSJ/index

mempengaruhi aroma kamaboko.

\section{Warna}

Hasil pengujian menunjukkan nilai rata-rata parameter warna kamaboko cumi-cumi 2,73 - 4,2 yang berarti panelis menilai dari netral sampai suka. Nilai kesukaan tertinggi pada perlakuan $\mathrm{K} 2$ dengan komposisi tepung tapioka $9 \%$ dan $\mathrm{NaCl} 6 \%$ sebesar 4,2 (suka), sedangkan nilai kesukaan terendah pada perlakukan K3 dengan komposisi tepung tapioka $12 \%$ dan $\mathrm{NaCl} 9 \%$ sebesar 2,73 (netral). Hasil parameter aroma dapat dilihat pada Gambar 3.

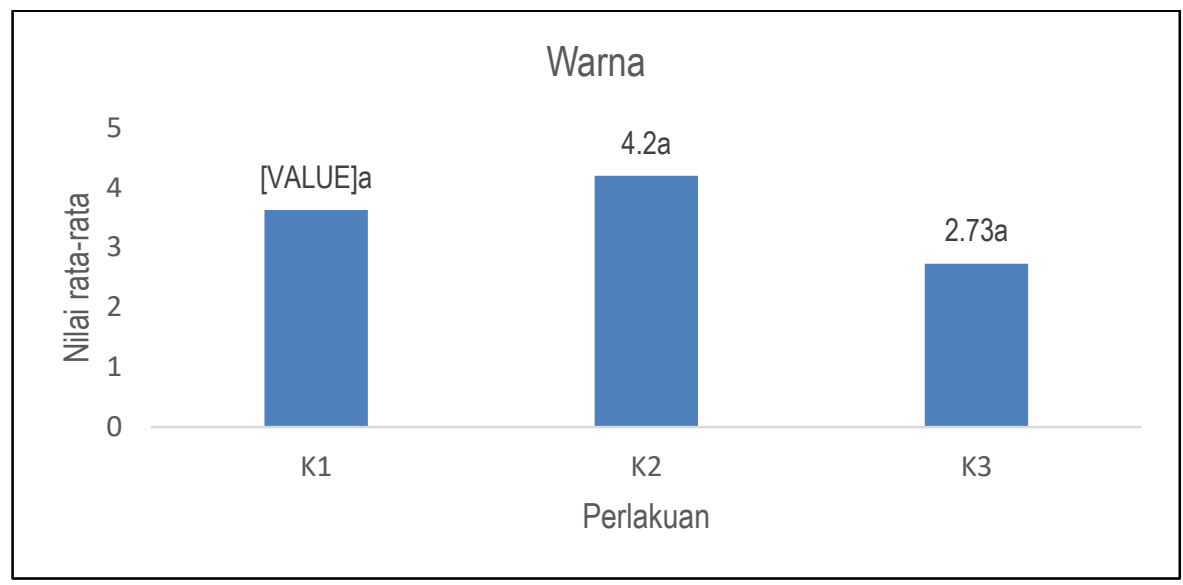

Gambar 3. Histogram parameter warna.

Hasil analisis KruskaLWallis menunjukkan bahwa perbedaan konsentrasi tepung tapioka dan $\mathrm{NaCl}$ tidak memberikan pengaruh terhadap warna kamaboko. Warna kamaboko cumi-cumi yang dihasilkan yaitu putih krem. Proses pencucian dapat memperbaiki warna kamaboko yang dihasilkan. Penambahan tepung tapioka dan $\mathrm{NaCl}$ yang semakin tinggi akan menurunkan nilai derajat putih kamaboko (Sarofa et al.2014). Penelitian Fajar et al. (2016) menunjukkan bahwa nilai derajat putih pasta ikan kurisi mengalami penurunan dengan bertambahanya konsentrasi tepung tapioka, nilai derajat putih pasta ikan kurisi tertinggi sebesar 74,02 dan yang terendah sebesar 71,90.

\section{Tekstur}

Hasil pengujian menunjukkan nilai rata-rata parameter warnakamaboko cumi-cumi $3,17-4,5$ yang berarti panelis menilai dari netral sampai suka. Nilai kesukaan tertinggi pada perlakuan $\mathrm{K} 2$ dengan komposisi tepung tapioka $9 \%$ dan $\mathrm{NaCl} 6 \%$ sebesar 4,5 (suka), sedangkan nilai kesukaan terendah pada perlakukan $\mathrm{K} 1$ dengan komposisi tepung tapioka $6 \%$ dan $\mathrm{NaCl} 3 \%$ sebesar 3,17(netral). Hasil parameter aroma dapat dilhat pada Gambar 4. 
Buletin JSJ, 3 (2), 2021, 63-69

Available online di: http://ejournal-balitbang.kkp.go.id/index.php/JSJ/index

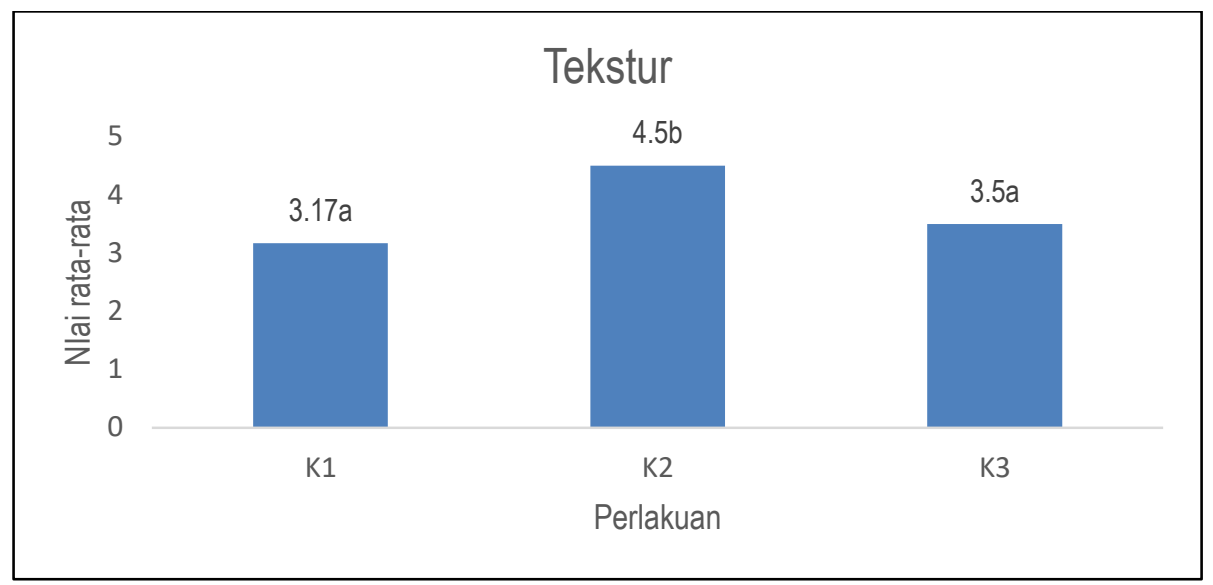

Gambar 4. Histogram parameter tekstur.

Hasil analisis Kruskal-Wallis menunjukkan bahwa perbedaan konsentrasi tepung tapioka dan $\mathrm{NaCl}$ memberikan pengaruh terhadap tekstur kamaboko. Hasil uji lanjut juga menunjukkan adanya perbedaan nilai rasa masing-masing perlakuan. Tepung tapioka merupakan bahan pengikat yang dapat membuat kamaboko menjadi kenyal, elastis. Lekahena (2016) menyatakan bahwa penggunaan bahan pengikat dapat membantu proses gelatinisasi, yang akan menghasilkan produk yang baik dan berpengaruh terhadap komposisi gizi. Hasil penelitian Fajar et al. (2016) menunjukkan bahwa penambahan konsentrasi tepung tapioka memberikan pengaruh terhadap tekstur pasta ikan kurisi.

\section{Uji Lipat}

Uji lipat merupakan salah satu pengujian mutu kamaboko yang dilakukan dengan cara memotong ketebalan 4-5 milimeter kemudian dilipat untuk mengtahui tingkat elastisitas kamboko. Hasil uji lipat kamaboko cumi-cumi dapat dilihat pada Gambar 5.

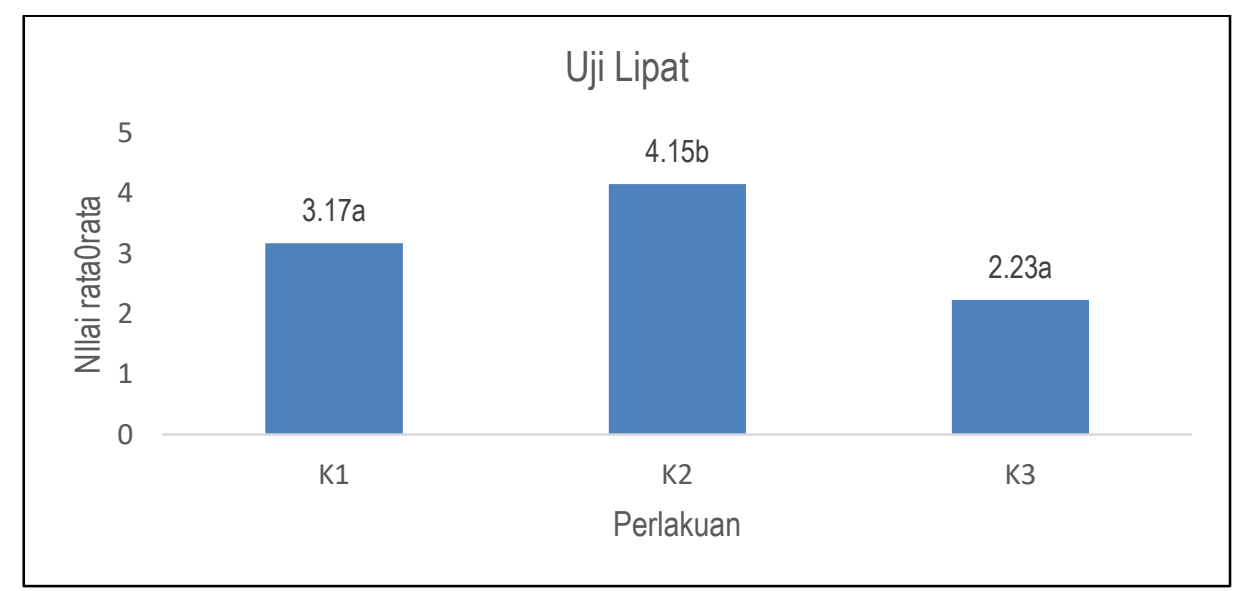

Gambar 5. Histogram uji lipat

Gambar 5 menunjukkan bahwa rata-rata nilai uji lipat kamaboko cumi-cumi 2,23-4,15. Nilai uji lipat tertinggi pada perlakuan K2 dengan komposisi tepung tapioka $9 \%$ dan $\mathrm{NaCl} 6 \%$ sebesar 4,15 (tidak retak bila dilipat satu kali), sedangkan nilai uji lipat terendah pada perlakukan $\mathrm{K} 3$ dengna komposisi tepung tapioka 12\% dan $\mathrm{NaCl}$ 9\% sebesar 2,23 (retak bila dilipat satu kali). Hasil analisis Kruskal - Wallis menunjukkan bahwa perbedaan konsentrasi tepung tapioka dan $\mathrm{NaCl}$ memberikan pengaruh terhadap uji lipat kamaboko. Hal ini dikarenakan selama proses pengolahan dan pemanasan tepung tapioka dapat meningkatkan 
daya ikat air. Garam (NaCl) juga berfungsi untuk meningkatkan kekuatan gel kamaboko. Sulistyaningrum dan Norhayani (2017) menyatakan bahwa larutan garam akan memudahkan ekstraksi aktin dan myosin pada daging ikan. Konsentrasi garam mempengaruhi proses ekstraksi ini, jika konsentrasi garam sedikit maka aktomiosin tidak dapat diekstrak dalam jumlah besar, sedangkan jika konsentrasi garam terlalu banyak maka akan terjadi pengendapan dan protein tidak larut.

\section{Uji Gigit}

Uji gigit dilakukan untuk mengetahui tingkat elastisitas dan kekenyalan kamaboko cumi-cumi.. Nilai rata-rata uji gigit kamaboko cumi-cumi berkisar antara $3,35-7,7$. Nilai uji gigit tertinggi pada perlakuan K2 sebesar 7,7. Hasil uji gigit kamaboko cumi-cumi dapat dilihat pada Gambar 6.

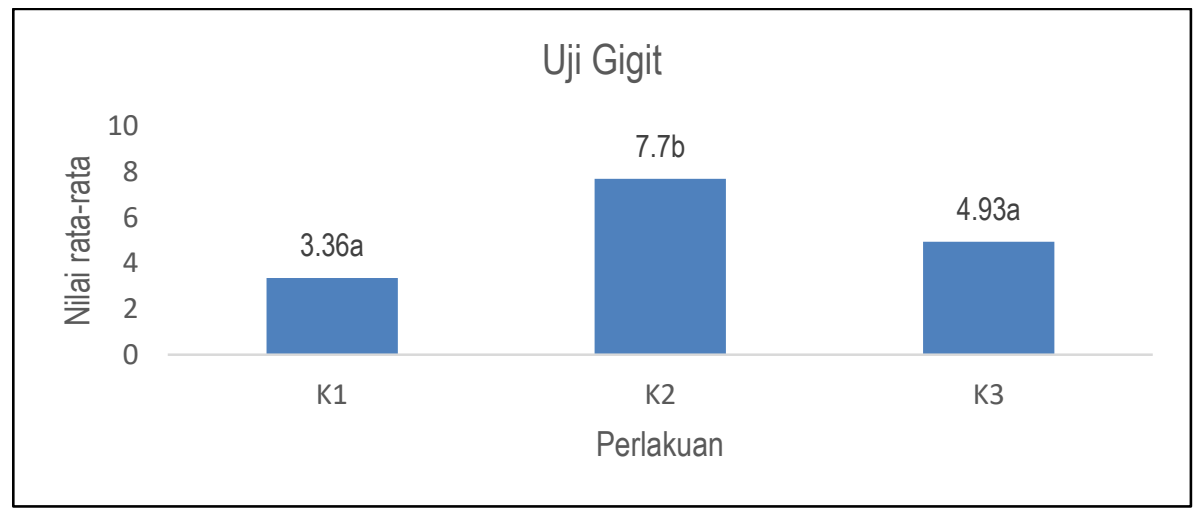

Gambar 6. Histogram uji gigit

Hasil analisis Kruskal-Wallis menunjukkan bahwa perbedaan konsentrasi tepung tapioka dan $\mathrm{NaCl}$ memberikan pengaruh terhadap nilai uji gigit kamaboko. Perbedaan konsentrasi bahan tambahan (tepung tapioka dan $\mathrm{NaCl}$ ) mempengaruhi kekuatan gel kamaboko sehingga nilai uji gigit kamaboko juga berpengaruh. Sulistyaningrum dan Norhayani (2017) menyatakan bahwa konsentrasi penambahan bahan (garam, tepung) berpengaruh terhadap elastisitas dan nilai uji gigit kamaboko yang dihasilkan.

\section{KESIMPULAN}

Kamaboko cumi-cumi dengan variasi penggunaan tepung tapioka dan $\mathrm{NaCl}$ memberikan pengaruh yang berbeda nyata terhadap penilaian panelis pada parameter rasa, tekstur, uji lipat dan uji gigit. Perlakuan yang terbaik yaitu perlakuan K2 dengan komposisi tepung tapioka 9\% dan $\mathrm{NaCl} 6 \%$, dimana semua parameter panelis memberikan penilaian tertinggi.

\section{DAFTAR PUSTAKA}

Anwar, C., Aprita, I, K., Irmayanti. (2019). Kajian Penggunaan Jenis Ikan dan Tepung Terigu Pada Kualitas Fisik dan Organoleptik Kamaboko. Journal of Fisheries and Marine Research. 3(3):288-300.

Badan Pusat Statistik Jakarta Pusat [BPS]. (2019). Statistik Indonesia Tahun 2019. Jakarta Pusat: Badan Pusat Statistik.

Fajar, R., Riyadi, P.H., \& Anggo, A.D. (2016). Pengaruh Kombinasi Tepung Biji Nangka (Artocarpus heterophyllus Lam k.) dan Tepung Tapioka Terhadap Sifat Fisik dan Kimia Pasta Ikan Kurisi (Nemipterus sp.). J.Peng \& Biotek.Hasil Pi. 5(4): 59-67. 
Buletin JSJ, 3 (2), 2021, 63-69

Available online di: http://ejournal-balitbang.kkp.go.id/index.php/JSJ/index

Hasnelly, Achyadi., N, S., \& Fatimah, F, S. (2020). Karakteristik Kamaboko dengan Substitusi Tepung Ubi Jalar dan Tinta Cumi-CUmi (Loligo sp.). Jurnal Pengolahan Hasil Perikanan Indonesia. 23(2): 333-341.

Hulalata A, Daisy M.M., \& Rastutu, W.P. (2013). Studi Pengolahan Cumi-Cumi (Loligo Sp) Asin Kering Dihubungkan dengan Kadar Air dan Tingkat Kesukaan Konsumen. Jurnal Media Teknologi Hasil Perikanan. Vol 1(2). 26-33.

Lekahena, V, N, J. (2016). Pengaruh Penambahan Konsentrasi Tepung Tapioka Terhadap Komposisi Gizi dan Evaluasi Sensori Nugget Daging Ikan Madidihang. Jurnal IImiah Agribisnis dan Perikanan. 9(1):1-8.

Mao, W., Mika, F., Noboru, F. (2006). Gel Strength of Kamaboko Gels Produced by Microwave Heating. Food Science and Technology Research. 12(4):241-246.

Sarofa U.Sudaryati Hp. Syaiful B. 2014. Evaluasi Kualitas Kamaboko Ikan Manyung (Arius Thalassinus) dengan Variasi Penggunaan Tapioka dan Nacl. Jurnal Rekapangan. Vol 8(1). 50-57.

Sulistyaningrum, T, W. \& Norhayati. (2017). Studi Subtitusi Tepung Tapioka dengan Tepung Maizena Terhadap Fisik Kamaboko Ikan Belut (Synbrancus bengalensis). Jurnal IImu Hewani Tropika. 6(2).90-94.

Suryaningrum., D., Murdinah., \& Arifin M. (2000). Penggunaan Kappa-Karaginan sebagai Penstabil pada Pembuatan Fish Meat Loaf dari Ikan Tongkol (Euthyinnus pelamys. L). Jurnal Penelitian Perikanan Indonesia. 8(6), 33-43. 